\title{
Students' Perception towards Technology in Learning English as a Foreign Language: A Case Study of Higher Secondary Students of Pabna, Bangladesh.
}

\author{
Sayed Rafiqul Hasan Milon ${ }^{\mathrm{a}, 1}$, Md. Hafiz Iqbal ${ }^{\mathrm{b}, 2}$ \\ ${ }^{a}$ Assistant Professor, Department of English, Pabna Government College. Pabna-6600, Bangladesh \\ ${ }^{b}$ Assistant Professor, Department of Economics, Government Edward College. Pabna-6600, Bangladesh
}

\begin{abstract}
The ever increasing impacts of globalization and technological development have transformed our learning patterns to a large extent. Learning English as a foreign language is not an exception as technology pervades all aspects of modern life in general and the communication by using English language in particular. The challenges of learning English in Bangladesh are many and Pabna is one of the leading districts. This paper attempts to examine higher secondary level students' attitude and perception towards their technology skill, usage patterns, perceived benefits of and challenges to using technology in learning English. To meet the research objectives, this study depends upon relevant literatures, documents, and observations and carries out questionnaire survey. One hundred and twenty $(\mathrm{n}=120)$ students from three government colleges of Pabna are randomly selected for interview. The findings indicate that technology tools like computer softwares, social networking websites, online videos, mp3 podcasts, smart phone and tablet apps have positive impacts and can be very much effective in improving students' language skills. It is expected that outcome of this study will provide potential pedagogical implications for developing English learning skills (reading, writing, speaking and listening) and establish ground for further research in this area.
\end{abstract}

Keywords: Technology based English Learning, Higher secondary students, Pabna, Bangladesh

\section{INTRODUCTION}

English is taught as a compulsory subject up to the under grade level in Bangladesh or in some cases used as a medium of instruction across subjects in Bangladesh. Its importance lies not only in success in examinations (Fakeye and Yemi 2009, Graham 1987) but also in research through books and the internet. Hasman (2004) contends that English has been established as the language of science and technology. According to Coleman (2010), compared to other languages English still has a dominant role. Besides, the relationship between English and employability is a significant one. Employability can be viewed as the ability to get a job, maintain it or get a new one (Kirubahar et al. 2010). In some cases, this will depend on ability to speak English fluently and to effectively communicate one's ideas orally. Coleman (2010) argues that several early studies have failed to find convincing evidence linking English to the economic development of the individual or nation. However, some recent studies are starting to show that there may indeed be a positive relationship between English and employability. Thus English is one of the determining factors of development as well.

The role of technology in learning English, the most important universal language can never be over emphasized. Information technology pervades all aspects of modern life, and with the help of globalization, it is on its triumphant march. The web places an unprecedented amount of information at the hands of individual users all around the globe (Warschauer, 1999). Though Bangladesh is heading towards the goal of digital Bangladesh, the introduction of technology at different educational level and its positive impacts have not been noticed yet (need evidence. Otherwise it is meaning to say). The situation of English language teaching and learning in Bangladesh is not standard (EIA, 2009a). Rigid, unhelpful, old-fashioned and non-active teaching practices, chalk and talk kinds of teacher-dominated lecture-based pedagogy remain the norm in Bangladeshi school culture where students are in a passive role, limited to memorizing facts and reciting them back to their teacher (Shohel and Howes, 2008; Shohel,

\footnotetext{
${ }^{1}$ Corresponding author. Tel.: +88 01711318608

E-mail address: srhmilonraj@gmail.com (S. R. H. Milon), vaskoriqbal@gmail.com (M. H. Iqbal)

${ }^{2}$ Tel... +88 $01717278232 ;+8801776196953$.
} 
2008). But when teaching methods for language learning across the globe have gone through massive changes over time we are still delaying. According to Rahman (1998), a student of Bangladesh spends about 1600 hours learning English before getting into University where 1000 hours instructional time is enough to become proficient in a language. It is a matter of great sorrow that Bangladeshi students cannot interact in English even after spending so many hours in learning English. Hence the necessity to understand the students' real perception of the use of technology in language learning with special reference to the problems and prospects as well.

Learning the English language is not an easy task (Ishihara and Cohen, 2014). But in reality, it is easy to say that technology based learning English can promote our efficiency to learn English. Spell checker, digital Oxford dictionary, web based IELTS, pronounce or phonetics, and contraction practice can help to improve students' learning English well. Technology therefore can be an inevitable tool for teachers and learners as it can provide an instantaneous 24 hour language learning environment for all (need evidence). Advantage of using the technological medium for language instruction is the ease and timeliness of access. The use of digital libraries and thesauri has facilitated quicker learning and has substantially improved learners' vocabularies. The use of technology is necessary because technological advancements have led to breaking barriers, and new domains have been explored within this global and informational age. (Salmah and Alsulami, 2016).Learning a language is a life-long process. Through multimedia with its variety of applications either online or offline learners can access their lessons and information from anywhere and at any time. According to Lim and Oakley (2013),

"The use of computers and the internet no longer need to be positioned in fixed places, mobile technologies allow interaction via text messaging and access to the internet wherever and whenever one wants."

The teaching of English as a Foreign Language (EFL) in Bangladesh has always been difficult and challenging because students fail to see its relevance to their immediate and future needs except for examination purposes. Bangladeshi students follow syllabus of compulsory English up to grade twelve, sit for written examination, get good grades as well but hardly gain the ability to communicate effectively in English. Today technology is providing numerous opportunities and many countries are getting benefitted by it while Bangladeshi students are lagging behind due to lack of technological facilities, lack of awareness and knowledge in the use of technology, budget constraint, lack of computer training at the primary level, lack of access to computers and internet. Like other parts of Bangladesh the higher secondary level students of different government colleges of Pabna have crossed several stages of their educational career without proficiency in English. The objective of the study is to examine the perception of higher secondary students of Pabna city towards the role of technology in enhancing learning English as a foreign language. It is expected that findings of this study will provide potential pedagogical implications for developing English learning (reading, writing, speaking and listening) and establish ground for further research in this area. It is also expected that findings of this study will help policy makers, curriculum planners, language educators and language learners in relevant ways.

\section{LITERATURE REVIEW}

The reviews of the literature on technology and learning English show that very few studies were conducted in countries like Bangladesh that faces so many challenges like lack of necessary equipments, infrastructures ,proper motivation and mind set of the students and so forth. In order to find out the students' perception of technology assisted language learning in Bangladesh, some recent and past research findings have been compiled here to analyze different aspects of technology based learning of language.

English language does not belong to any specific country or nation and the importance of learning English is the demand of time now. English has become the global language as 80 percent of the internet content is in English, 70 percent of the emails sent around the world are written in English and 60 percent of the world publications are also in English (Austin, 2007). E-learning is till now a new concept for the Bangladeshi students' (Akbar, 2005). To introduce e-learning education system, there are a number of challenges need to be faced in Bangladesh. Except the urban areas, computer and internet connection is not accessible for common people in many areas.

Lai and Kritsonis (2006) believe that computer can provide learners with many fun games and communicative activities that reduce learners stress and anxiety. Technology based language learning can help learners improve their linguistic skills, affect their attitude towards language learning and build self-confidence. Robertson, et al., 2000 observe that the learners of computer assisted language programs have higher self-esteem rating than the regular students. Their findings also showed that computer application improved the students' ability in punctuation, grammar and spelling.

Online tools can play a great role in raising awareness about English language. Kavaliauskiene et al., (2006) find that using blog in EFL writing class makes the learners feel that their writing is not only for the classmates or 
teachers but for the whole world and thus it raises their language awareness. According to Blattner and Fiori (2009), Facebook is the fastest growing and best known site on the internet that has more than 100 million members. They also believe that Facebook can be a powerful learning tool since it allows its user to experience various patterns of interaction. In 2006, Stuzman explored from his survey that university going students are the largest users of Facebook . Veer (2010) considers Facebook as a "hip, hot and happening site" where members can "witness" each other's life by viewing and sharing numerous quantities of information. Facebook people can imitate different types of real life conversation as they can poke a friend, give a virtual hi or hello, write on somebody's wall and send cyber gifts. Thus, Facebook offers several forums for students where they can find job, roommate or even textbook (Blattner and Fiori, 2009).

You tube can play a greater role in learning language and it is also increasingly used in teaching and learning across the globe. The impacts of YouTube video clips on teaching and learning for EFL Taiwanese learners regarding their listening skill performance were examined by Kuo (2009) and positive impact was found there.

Pozzobon (2008) recommends the website called Podbean that offers the opportunity of creating, listening and subscribing to podcast without any cost. According to Nagel (1999), exchanging email among the students of a classroom motivates them to participate and it does not require being very expert in using computer. Knowledge of different electronic communication like email, discussion board and file sharing are important to collaborate with students and colleagues (Kessler, 2006).

Wikis is a collaborative website that can help students to develop their writing skill (Holtman, 2009; Erban et al., 2009;. Erban et al., 2009:173 suggest the following websites that may help teachers and students:

- www.useingenglish.com

- www.sitesforteachers.com

- www.esl-galaxy.com

- www.atozteacherstuff.com

- www.coollessons.org

www.eslcafe.com

\section{METHODOLOGY}

This study follows qualitative approaches by using a self- structured questionnaire. Qualitative research involves the studied use and collection of a variety of empirical materials - case study, personal experience, introspective, life story, interview, observational, historical, interactional, and visual texts - that describe routine and problematic moments and meanings in individuals' lives. Accordingly, qualitative researchers deploy a wide range of interconnected methods, hoping always to get a better fix on the subject matter at hand. (Denzin and Lincoln, 1994: 2).So to analyse the perception of the respondents qualitative approaches have higher potential to reach the objectives of the study.

Likert-type scale is used to figure out the data. Likert (1932) developed the principle of measuring attitudes by asking people to respond to a series of statements about a topic, in terms of the extent to which they agree with them, and so tapping into the cognitive and affective components of attitudes. Likert-type or frequency scales use fixed choice response formats and are designed to measure attitudes or opinions (Bowling, 1997; Burns, \& Grove, 1997). These ordinal scales measure levels of agreement/disagreement.

The study conducted its survey in Pabna city, the Northwest region of Bangladesh. One hundred and twenty ( $\mathrm{n}=120)$ students of higher secondary level from three government colleges have been chosen on random basis -forty students from each college.

\section{RESULT AND DISCUSSION}

Table1 Students perception of technology types used frequently to develop English language skills

\begin{tabular}{|l|l|l|l|}
\hline \multicolumn{1}{|c|}{ Items } & \multicolumn{1}{|c|}{ Always } & \multicolumn{1}{|c|}{ Sometimes } & \multicolumn{1}{c|}{ Never } \\
\hline 1.Watching TV, Videos and Movies & $12(10 \%)$ & $92(76.66 \%)$ & $16(13.33 \%)$ \\
2.Listening to radio, news and lectures & $04(03.33 \%)$ & $56(46.66 \%)$ & $60(50 \%)$ \\
3.Communicating with friends/relatives through technology & $24(20 \%)$ & $68(56.66 \%)$ & $28(23.33 \%)$ \\
4.Searching websites to get information & $22(18.33 \%)$ & $70(58.33 \%)$ & $28(23.33 \%)$ \\
\hline
\end{tabular}

(Source: Prepared by the authors, 2017)

Table 1 shows that $92(76.66 \%), 56(46.66 \%), 68(56.66 \%)$ and $70(58.33 \%)$ students respectively use various types of technologies sometimes. Only handful of $12(10 \%), 04(03.33 \%), 24(20 \%)$ and $22(18.33 \%)$ respondents respectively always use technology of different types while $16(13.33 \%), 60(50 \%), 28$ (23.33\%),and 28 $(23.33 \%)$ students respectively never use any type of technology for learning English. Thus sometimes is more 
dominating option than the other two options e.g. always and never. Students are not much interested in mentioned items. As per the field level observations, most of the 12 grade students pass busy time in class, engaging with private tutor and study. In addition, guardians of the students are not interested to provide smart phone and relevant devices due to safety and security. It is also noticeable that students lie in always group represent high income households and students lie in the never group represents low income households and they have no ability to purchase smart phone or relevant devices.

Table2 Students perception of online tools usage frequency in learning English.

\begin{tabular}{|l|c|c|c|}
\hline \multicolumn{1}{|c|}{ Tools } & Always & Sometimes & Never \\
\hline 1.Computer software for learning English & $4(3.33 \%)$ & $20(16.66 \%)$ & $96(80 \%)$ \\
2.Twitter,Facebook, Whats App, and Blogs & $16(13.33 \%)$ & $68(56.66 \%)$ & $36(30 \%)$ \\
3.YouTube, Skype, MP3 player, and podcasts & $32(26.66 \%)$ & $36(30 \%)$ & $52(43.33 \%)$ \\
4.Smartphone or tablet apps & $100(83.33 \%)$ & $08(06.66 \%)$ & $12(10 \%)$ \\
\hline
\end{tabular}

(Source: Prepared by the authors, 2017)

The results show that majority part of students and it covers 80 percent students are not motivated enough to learn English via computer software since personal computer are not so available to all. But 69.99 percent students are agreed in using Twitter, Facebook, WhatsApp, and Blogs to improve their English. "Youtube" and apps such as "Skype" as well as podcasts and mp3 players all have a positive impact on their English language learning. Finally, 100 students $(83.33 \%)$ believe that smart phone and tablet apps can improve their English language learning. Thus, smart phone based online tools are most frequently accessed by the students as most of them at least have a smart phone of their own.

Table 3 Students perception of the impacts of technology on learning English

\begin{tabular}{|c|c|c|c|c|c|}
\hline Items & SA & A & $\mathrm{U}$ & D & SD \\
\hline $\begin{array}{l}\text { 1. Provides enjoyment while } \\
\text { learning English language. }\end{array}$ & $74(61.66 \%)$ & $38(31.66 \%)$ & & $08(06.66 \%)$ & \\
\hline $\begin{array}{l}\text { 2. Increases confidence through } \\
\text { proper motivation. }\end{array}$ & $42(35 \%)$ & $52(43.33 \%)$ & & $22(18.33 \%)$ & $04(03.33 \%)$ \\
\hline $\begin{array}{l}\text { 3. Enhances four skills } \\
\text { considerably. }\end{array}$ & $38(31.66 \%)$ & $70(58.33 \%)$ & & $12(10 \%)$ & \\
\hline $\begin{array}{l}\text { 4.Makes learning easy and } \\
\text { affordable at any time and } \\
\text { from anywhere }\end{array}$ & $71(59.16 \%)$ & $45(37.5 \%)$ & & $04(03.33 \%)$ & \\
\hline $\begin{array}{l}\text { 5.Increases active involvement } \\
\text { of the students }\end{array}$ & $28(23.33 \%)$ & $76(63.33 \%)$ & $08(06.66 \%)$ & $06(05 \%)$ & $02(01.66 \%)$ \\
\hline $\begin{array}{l}\text { 6.Leads to better academic } \\
\text { performance also }\end{array}$ & $29(24.16 \%)$ & $70(58.33 \%)$ & $07(05.83 \%)$ & $10(08.33 \%)$ & $04(03.33 \%)$ \\
\hline
\end{tabular}

NB: SA: Strongly Agree, A: Agree, U: Undecided, D: Disagree, SD: Strongly Disagree

(Source: Prepared by the authors, 2017)

Most of the respondents in Table 3 bear positive perception on the impacts of technology on learning English. 112 (93.32 percent), 94(78.33percent), 108 (89.99 percent), 116 (96.66 percent), 104 (86.66 percent),and 99(82.49 percent) students respectively have agreed that technology can provide enjoyment while learning, enhances confidence and motivation, develops four skills (speaking, reading, writing and listening), makes learning easy and timely, increases learners' active involvement, and thus leads to better academic performances. Similarly, 113 (94.16 percent) and 76 (63.33 percent) students respectively have opposed that technology makes learning English boring and difficult and promotes time-wasting hampering regular study. This scenario implies that clearly students believe that technology has more positive impacts than negative ones. 
Students' Perception towards Technology in Learning English as a Foreign Language: A Case

Table 4: Students' perception of the difficulties and challenges on the way of using technology effectively in learning English.

\begin{tabular}{|l|l|l|l|l|l|}
\hline ITEMS & SA & \multicolumn{1}{|c|}{ A } & U & D & SD \\
\hline 1.Financial constraints & 26 & 60 & 05 & 25 & 04 \\
& $21.66 \%$ & $50 \%$ & $04.16 \%$ & $20.83 \%$ & $03.33 \%$ \\
\hline 2.Costly internet packages & 40 & 70 & 02 & 08 & - \\
& $33.33 \%$ & $58.33 \%$ & $01.66 \%$ & $06.66 \%$ & \\
\hline 3. Lack of basic ICT skills & 24 & 53 & 02 & 31 & 10 \\
& $20 \%$ & $44.16 \%$ & $01.66 \%$ & $25.83 \%$ & $08.33 \%$ \\
\hline 4. Problem of internet connectivity & 28 & 64 & 08 & 18 & 02 \\
& $23.33 \%$ & $53.33 \%$ & $06.66 \%$ & $15 \%$ & $01.66 \%$ \\
\hline 5.High cost of technological items & 22 & 72 & 09 & 15 & 02 \\
& $18.33 \%$ & $60 \%$ & $75 \%$ & $12.5 \%$ & $01.66 \%$ \\
\hline 6.Lack of strong ICT policy & 14 & 32 & 48 & 22 & 04 \\
& $11.66 \%$ & $26.66 \%$ & $40 \%$ & $18.33 \%$ & $03.33 \%$ \\
\hline 7.Lack of proper guidance and motivation & 27 & 68 & - & 25 & - \\
from teachers & $22.5 \%$ & $56.66 \%$ & & $20.83 \%$ & \\
\hline 8.No use of technology based teaching & 73 & 45 & 2 & & \\
materials in college classroom. & $60.83 \%$ & $37.5 \%$ & $01.66 \%$ & & \\
\hline 9.Lack of students' interest and willingness & - & 15 & 18 & 76 & $63.33 \%$ \\
& & $12.5 \%$ & $15 \%$ & $09.16 \%$ \\
\hline
\end{tabular}

NB: SA: Strongly Agree, A: Agree, U: Undecided, D: Disagree, SD: Strongly Disagree

(Source: Prepared by the authors, 2017)

Table 4 illustrates the challenges usually faced by the students on the way of pursuing technology as a learning medium. Most of the students 118(98.33percent) think that there is no use of technology in their English classrooms which may be a good cause of very little motivation among them in using technology for learning. For instance, as many as 95 (79.10percent) students are of the view that lack of proper guidance and motivation from teachers is the factor affecting the use of technology in language learning while only 25(20.83 percent) are of the opposite view .Many of the respondents, 110 (91.66percent) opine that costly internet packages are on the way of their smooth use of technology in language learning .Many respondents, 94(78.83 percent) believe that costly technological items are creating problems to the proper utilization of technology in language learning specially for the poor while only 17 (14.16 percent) disagreed. Financial constraints are worth noticing in this context since 86(71.66percent) students believe it as a barrier on the way of pursuing technology for learning. Problem of internet connectivity and lack of technology skills are seen as hindrances to effective use of technology in language learning by 92(76.66 percent) and 77 (64.16 percent) respondents respectively. Again, lack of interest and willingness of the students in using technology for learning English is also supported by many students 87(72.49 percent). However about strong ICT policy a remarkable number of students 48 (40 percent) remain undecided which may be due to their experience so far about the government policies and its slow and ineffective implementation.

\section{CONCLUSIONS AND RECOMMENDATION}

As far as the findings of the study are concerned for Bangladesh integrating technology into English language teaching and learning is very much necessary. It is high time to revitalize English language education across the country through technology. As Hawkins (2002) noted, It is time to collectively change our approach to the learning process, and particularly, take advantage of the power of technology to improve learning outcomes, enhance economic opportunities, foster greater creativity, and realize the dreams of disadvantaged youth in developing countries. (p. 43)Though most of the students do not use technology for learning purposes they bear positive perceptions that technology can be used for enhancing overall learning English process .However there are some challenges on the way of technology pursuit by the students which have to be removed urgently creating necessary policies.Some recommendations are as follow:

1. Technology-supported hardware, software, Net connectivity, audio visual aids, teaching aids and other accessories should be made available to the students giving subsidies in this sector.

2. To strengthen students' digital literacy skill and knowledge, training on technology application in learning should be given to all students. Participants with negative perceptions were less skilled in technology use. Changing individuals' negative perceptions into positive is an essential need to increase literacy skills. Accordingly, "Such 
attitudes are developed when (they) are sufficiently comfortable with technology and are knowledgeable about its use" (as cited in Khan, Hasan, \& Clement, 2012).

3. Language classrooms are to be furnished with internet connections and technologies like computers, interactive white board, internet connectivity, TV and so on.

4. It is highly suggestive to manage cost effective technologies with a view to reducing the expenses. It will enhance the smooth process of technology-mediated teaching/learning in education.

5. Computer softwares, social networking websites, online videos, mp3 podcasts, smart phone and tablet apps have positive impacts and therefore these tools should be introduced in the classroom by the teachers with due motivation.

The findings implies that students of Pabna, Bangladesh have shown positive perception of technology adoption into their learning practices than traditional pedagogy. It is, therefore, hoped that by following the recommendations, an effective technology driven learning atmosphere can be created to facilitate English language learning. In addition, the findings of this study will be further helpful for the ELT experts, ESL/EFL teachers, students, curriculum designers and researchers.

\section{REFERENCES:}

[1] Akbar, M. S. (2005). E-learning in developing countries: Challenges and opportunities Bangladesh perspective. Proceedings of the SecondInternational Conference on E- learning for Knowledge-Based Society. August 4-7, Bangkok.

[2] Alsulami, S. (2016) The Effects of Technology on Learning English as a Foreign Language Among Female EFL Students at Effatt College: An Exploratory Study. Canadian Academy of Oriental and Occidental Culture. Vol. 12, No. 4, 2016, pp. 1-16

[3] Austin, C. (October 3, 2007). Global access through the global language. The Daily Star. Retrieved from http://www.thedailystar.net/newDesign/newsdetails.php?nid=6349

[4] Blattner, G. and Fiori, M. (2009). Facebook in language classroom: promises and possibilities. International journal of instructional technology and distance learning, 6(1), 17-28.

[5] Bowling A (1997) Research Methods in Health. Open University Press, Buckingham.

[6] N \& Grove SK (1997) The Practice of Nursing Research Conduct, Critique, \& Utilization. W.B. Saunders and Co., Philadelphia.

[7] Creswell, J. W. (2003). Research Design: Qualitative,Quantitative, and Mixed Approaches. Second Revised ed. London: Sage Publications Ltd.

[8] Crystal, D. (2006). Language and the Internet. 2nd edition. Cambridge: Cambridge University Press.

[9] Coleman, H. (2010). The English Language in Development. London: British Council. Available online at www.teachingenglish.org.uk/transform/book

[10] Dede, C. (2005). Planning for neomillennial learning styles. EDUCAUSE Quarterly,28(1), 7-12.

[11] Denzin, N and Lincoln, Y (Eds) (1994) Handbook of Qualitative Research, Thousand Oaks (Calif),Sage

[12] EIA (2009). An observation study of English lessons in primary and secondary schools in Bangladesh. Baseline Study 3. Dhaka: English in Action.

[13] Erban, T., Ban, R. and Castaneda, M. (2009). Teaching English Language Learners Through Technology. New York: Routledge.

[14] Fakeye, D.O. and Yemi, O. (2009). English language proficiency as a prediction of academic achievement among EFL students in Nigeria. European Journal of Scientific Research, 37(3), 490-495.

[15] Hasman, M.A. 2004. The role of English in the 21st century. TESOL Chile 1(1), 18-21.

[16] Hawkins, R. J. (2002). The lessons for ICT and education in the developing world.

[17] Holtman, L. (2009). Using Wikis in the teaching of a short course on history and philosophy of

[18] science. International Journal of Instructional Technology and Distance Learning,

[19] 6(1), 29-37.

[20] Ishihara, N., \& Cohen, A. D. (2014). Teaching and learning pragmatics: Where language and culture meet. New York: Routledge.

[21] Kavaliauskiene, G., Anusiene, L. and Maziekiene, V. (2006). Weblogging: Innovation for Communication in English. Electronic Journal of Foreign Language Teaching, 3(2), 220-233.

[22] Kessler, G. (2006). Assessing CALL Teacher Training: What are we doing and what could we do better. In P. Hubbard and M. Levy. (Eds.). Teacher Education in CALL. Philadelphia: John Benjamin.

[23] Khan, S. H., Hasan, M., \& Clement, C. K. (2012, July). Barriers to the Introduction of ICT in 
Education in Developing Countries: The example of Bangladesh. International Journalof Instruction, 5(2), 61-80

[24] Kirubahar, J.S., Santhi, V.J. and Subashini, A. 2010. Personal and labour market environment

[25] factors in English for employability: A case study of KSA. Language in India 10(4), 21-

[26] . Available online at www.languageinindia.com

[27] Lai, C.C \& Kristonis, W. A. 2006. The Advantages and Disadvantages of Computer Technology in Second Language Acquisition. Doctoral Forum National Journal for Publishing and Mentoring Doctoral Students Research Volume 3 Number 1, 2006

[28] Lim, C.P. \& Oakley, G., (2013). Information and Communication Technology (ICT) in Primary Education: Opportunities and Supporting Conditions. In: Tay, L. Y. and Lim, C.P. (Eds.), Creating.

[29] i-Li, K. (2009). The effects of YouTube listening/viewing activities on Taiwanese EFL Learners' Listening Comprehension. 221-22.

[30] Nagel, P. S. (1999). Email in the virtual ESL/EFL classroom. The Internet TSL Journal, 5(7), retrieved on September 23, 2011 from http://iteslj.org/Articles/Nagel-Email.html

[31] Pozzobon, C. (2008). Podcast and Literature. Entre Lenguas, 13, 111-115.

[32] Rahman, A. (1998). English teaching in Bangladesh: Problems and Prospects. Journal of theInstitute of Modern Language, 8, 95-101.

[33] Robertson, M. Line, M., Jones, S., \& Thomas, S.,(2000). International Students, Learning Environments and Perceptions: a case study using the Delphi technique . Higher

Education Research \& Development, Vol. 19, No. 1, 2000

[34] Shohel, M. M. C. and Howes, A. J. (2008). Informality of teaching and learning in non formal schools: Socio cultural processes as mesosystems of student development. Education 3- $\quad 13,36(3), 293-309$.

Stuzman, F. (2006). An Evaluation of Identity-sharing Behavior in Social.iDMA Journal, 3(1). Retrieved from http://www.units.muohio.edu/codeconference/papers/papers/stutzman_track5.pdf

[35] Veer, E. A. V. (2010). Facebook: The Missing Manual. Sebastopol: O’Reilly Media.

[36] Warschauer, M. (1999). Electronic literacies: Language, culture, and power in online education. Mahwah, NJ: Erlbaum. 